Vita Purnamasari ${ }^{1}$, Sri Sundari ${ }^{1}$, Galuh Suryandari

${ }^{1}$ Magister Keperawatan Universitas Muhammadiyah Yogyakarta,Jl. Lingkar Selatan, Kasihan, Tamantirto, Bantul, Daerah Istimewa Yogyakarta 55183, Indonesia.

${ }^{2}$ Stikes Surya Global Yogyakarta, J. Ring Road Selatan, Blado, Potorono, Banguntapan, Bantul, Daerah Istimewa Yogyakarta 55196, Indonesia.

E-mail: vitafkikumy@gmail.com

\title{
Peningkatan Hasil Belajar Kognitif dan Harga Diri Mahasiswa Melalui Metode Cooperative Learning Tipe Jigsaw
}

Info Artikel:

Masuk : :14 September 2016

Revisi : : 24 November 2016

Diterima : 7 Desember 2016

DOI Number : 10.18196/ijnp.1153

\begin{abstract}
ABSTRAK
Cooperative Learning tipe Jigsaw merupakan metode pembelajaran inovatif, lima pokok elemen cooperative jigsaw dapat meningkatkan hasil belajar, ketrampilan interpersonal, harga diri serta motivasi. Tujuan penelitian untuk mengetahui pengaruh cooperative learning terhadap hasil belajar dan harga diri mahasiswa Stikes Surya Global Yogyakarta. Desain penelitian Quasy Eksperimen rancangan pretes postest with control group design, subyek penelitian mahasiswa Stikes Surya Global semester 2 dengan total sampling,jumlah responden 221 mahasiswa. Analisa data menggunakan Wilcoxon Signed Rank Test dan Mann Whitney Test. Hasil Penelitian menunjukkan terdapat perbedaan yang signifikan antara kelompok intervensi dan kelompok kontrol dengan $\mathrm{P}=0.000$ untuk variabel hasil belajar kognitif dan nilai $\mathrm{P}=0.000$ untuk variabel harga diri. Kesimpulan penelitian adalah Cooperative Learning Tipe Jigsaw meningkatkan hasil belajar mahasiswa dan harga diri mahasiswa Stikes Surya Global Yogyakarta .

Kata Kunci : cooperative learning, harga diri, hasil belajar, kognitif
\end{abstract}

\section{ABSTRACT}

Cooperative Learning Jigsaw type is an innovative learning, the five principal elements of cooperative jigsaw can improve learning outcomes, interpersonal skills, self esteem and motivation. The purpose of research to determine the effect of cooperative learning on learning outcomes and selfesteem students Stikes Surya Global Yogyakarta. The research design is Quasy Experimental design of posttest pretest with control group design, research subjects of Stikes Surya Global 2nd semester with total sampling, the number of respondents is 221 students. Data analysis using Wilcoxon Signed Rank Test and Mann Whitney Test. The results showed that there were significant 


\section{NURSING PRACTICES}

differences between intervention group and control group with $\mathrm{P}=0.000$ for cognitive learning and $\mathrm{P}=$ 0.000 for self esteem. The conclusion of this research is Cooperative Learning Jigsaw improve cognitive and student's self esteem Stikes Surya Global Yogyakarta.

Keywords:cognitive, cooperative learning, learning outcomes, self-esteem.

\section{PENDAHULUAN}

Pendidikan di bidang ilmu kesehatan mengalami perubahan pada pola dan cara belajar mahasiswa. Awalnya proses pembelajaran yang berpusat pada dosen atau Teacher Centered Learning (TCL) bergeser menjadi Student Centered Learning (SCL).

Fenomena mengajar secara konvensional yang kurang melibatkan mahasiswa secara langsung dalam proses belajar mengajar mengakibatkan mahasiswa menjadi kurang aktif dalam proses pembelajaran. Proses pembelajaran yang kurang maksimal menjadikan hasil belajar yang diperoleh mahasiswa kurang memuaskan (Uys, 2005). Hal ini dapat dilihat dari nilai ujian akhir semester mahasiswa yang tergolong rendah. Selain itu, nilai hasil belajar yang kurang memuaskan ini juga berdampak pada saat pelaksanaan Uji Kompetensi Ners Indonesia (UKNI).

Cooperative learning merupakan salah satu pembelajaran Student Centered Learning yang dapat diterapkan untuk memotivasi mahasiswa untuk lebih memahami materi pembelajaran. Cooperative Learning merupakan pembelajaran inovatif yang dilakukan dengan cara berdiskusi dengan teman secara aktif.

Cooperative learning merupakan pembelajaran yang didalamnya terdapat kerja sama antara mahasiswa yang dapat meningkatkan prestasi yang lebih tinggi oleh semua peserta (Lie, 2014). Peserta didik saling membantu, dengan demikian membangun sebuah komunitas yang mendukung, yang kemudian dapat meningkatkan kinerja masing-masing anggota. Kinerja dari masing-masing anggota kelompok tersebut akan meningkatkan harga diri mahasiswa.

Harga diri merupakan salah satu komponen utama yang mempengaruhi tingkat kinerja pada suatu profesi. Harga diri mempunyai pengaruh dalam keberhasilan pekerjaan, prestasi sekolah, dan hubungan interpersonal. Harga diri merupakan kebutuhan yang penting yang harus dimiliki oleh seorang perawat. Harga diri yang tinggi dapat membuat kinerja perawat yang lebih baik serta dapat meningkatkan keberhasilan dalam bekerja (Coopersmith, 2006).

Cooperative Learning tipe jigsaw merupakan salah satu tipe pembelajaran kooperatif yang menekankan mahasiswa untuk belajar secara berkelompok dan mengajarkan kepada mahasiswa untuk berkomunikasi yang baik di dalam kelompok. Cooperative Learning jigsaw merupakan salah satu metode pembelajaran yang inovatif sehingga diperlukan penelitian untuk menjawab adakah peningkatan kognitif dan harga diri mahasiswa melalui penerapan cooperative learning jigsaw.

\section{METODE}

Desain penelitian menggunakan Quasy Eksperimen rancangan pretes postest with control group design. Penelitian dilakukan Januari - Maret 2017. Intervensi dilakukan sebanyak 6 kali pertemuan dengan menggunakan intervensi metode cooperative learning untuk kelompok intervensi dan kelompok kontrol diberikan metode pembelajaran konvensional ceramah. Penelitian ini sudah lulus uji etik dari Fakultas Kedokteran dan IImu Kesehatan Universitas Muhammadiyah Yogyakarta dengan ethical clearance No. 040/EP-FKIKUMY/I/2017.

Subyek penelitian yang digunakan sebanyak 221 mahasiswa Stikes Surya Global Yogyakarta semester 2, pengambilan sampel dilakukan dengan cara total sampling. Kelompok intervensi terdiri dari 105 responden dan kelompok kontrol 116 responden. Selama penelitian berlangsung tidak terdapat responden yang drop out. Instrument yang digunakan adalah Rosenberg Self Esteem Scale untuk mengukur variabel harga diri, kuesioner berisi tentang pernyataan yang berkaitan dengan penerimaan di lingkungan dan penghargaan dari orang lain. Pengukuran variabel kognitif dengan menggunakan soal multiple choice yang sebelumnya sudah dilakukan item review soal. 
Uji Normalitas yang digunakan adalah Kolmogorov Smirnov. Analisis data penelitian menggunakan Wilcoxon Signed Rank Test dan Mann Whitney Test karena data tidak berdistribusi normal. Uji Normalitas data menggunakan uji Kolmogorov Smirnov.

\section{HASIL}

Hasil analisis karakteristik responden meliputi jenis kelamin, usia dan asal sekolah digambarkan pada tabel di bawah ini.

Tabel 1. Karakteristik Responden

\begin{tabular}{|c|c|c|c|c|}
\hline \multirow{3}{*}{$\begin{array}{l}\text { Karakteristik } \\
\text { Responden }\end{array}$} & \multicolumn{4}{|c|}{ Kelompok } \\
\hline & \multicolumn{2}{|c|}{ Perlakuan } & \multicolumn{2}{|c|}{ Kontrol } \\
\hline & $\mathrm{N}$ & $\%$ & $\mathrm{~N}$ & $\%$ \\
\hline \multicolumn{5}{|l|}{ Jenis Kelamin } \\
\hline Laki-Laki & 0 & 0 & 15 & 12.93 \\
\hline Perempuan & 105 & 100 & 101 & 87.06 \\
\hline \multicolumn{5}{|l|}{ Usia } \\
\hline \multicolumn{5}{|l|}{ 15-20 tahun } \\
\hline \multirow[t]{2}{*}{$>20$ tahun } & 98 & 93.33 & 100 & 86.20 \\
\hline & 7 & 6.67 & 16 & 13.79 \\
\hline \multicolumn{5}{|l|}{ Lulusan } \\
\hline \multicolumn{5}{|l|}{ SLTA Umum } \\
\hline \multirow[t]{2}{*}{ SMK Kesehatan } & 88 & 83.80 & 111 & 95.68 \\
\hline & 17 & 16.20 & 5 & 4.32 \\
\hline
\end{tabular}

Tabel 1 menunjukkan responden kelompok kontrol dan kelompok perlakuan berjenis kelamin perempuan. Umur responden kedua kelompok paling banyak berumur 15- 20 tahun. Proporsi responden dengan latar belakang pendidikan juga hampir sama yaitu dari lulusan SLTA umum atau SMK Non Kesehatan.

Perbedaan hasil belajar kognitif dan harga diri mahasiswa sebelum dan sesudah dilakukan intervensi dapat dilihat pada tabel berikut ini:
Tabel 2. Hasil Belajar Kognitif Mahasiswa Stikes Surya Global Sebelum dan Sesudah dilakukan Metode Pembelajaran Cooperative Jigsaw

\begin{tabular}{llll}
\hline Kelompok & \multicolumn{1}{c}{ Variabel } & Mediaan & P \\
\hline Intervensi & Pretest & 53.00 & 0.000 \\
\cline { 2 - 3 } & Postest & 93.00 & \\
\hline Kontrol & Pretest & 53.00 & 0.000 \\
\cline { 2 - 3 } & Postest & 76.00 & \\
\hline
\end{tabular}

Tabel 2 menunjukkan bahwa nilai hasil belajar mahasiswa antara kelompok intervensi dan kelompok kontrol mengalami peningkatan. Hasil uji statistik menunjukkan bahwa kelompok intervensi dan kontrol mengalami peningkatan yang bermakna $p=0.000$; $\alpha=0.05$

Hasil dari harga diri mahasiswa sebelum dan sesudah dilakukan perlakuan dapat dilihat pada tabel di bawah ini:

Tabel 3.Harga Diri Mahasiswa Stikes Surya Global Sebelum dan Sesudah dilakukan Metode Pembelajaran Cooperative Jigsaw.

\begin{tabular}{llllll}
\hline \multirow{2}{*}{ Kelompok } & \multicolumn{2}{c}{$\begin{array}{c}\text { Rendah } \\
(\%)\end{array}$} & $\begin{array}{c}\text { Sedang } \\
(\%)\end{array}$ & $\begin{array}{c}\text { Tinggi } \\
(\%)\end{array}$ & $P$ \\
\hline Intervensi & Pretest & 31.4 & 54.3 & 14.3 & \multirow{2}{*}{0.000} \\
\cline { 2 - 5 } & Postest & 0 & 5.7 & 94.3 & \\
\hline Kontrol & Pretest & 21.6 & 70.7 & 7.8 & \multirow{2}{*}{0.012} \\
\cline { 2 - 5 } & & 11.2 & 81.9 & 6.9 & \\
\hline
\end{tabular}

Tabel 3 menunjukkan prosentase harga diri meningkat pada kelompok intervensi. Peningkatan Harga diri pada kelompok intervensi secara statistik signifikan dengan nilai $P=0.000 ; \alpha=0.05$.

Hasil Belajar Kognitif dan Harga diri mahasiswa pada kelompok intervensi dan kelompok kontrol pretest dan potest dilakukan uji untuk mengetahui perbedaan diantara kedua kelompok. Uji tersebut menggunakan Mann Whitney Test untuk kedua variabel. Hasil uji variabel kognitif tersebut dapat dilihat pada tabel berikut ini: 


\section{NURSING PRACTICES}

Tabel 4. Perbedaan Hasil Belajar Kognitif Kelompok Intervensi dan kelompok Kontrol sebelum dan Sesudah Intervensi.

\begin{tabular}{|c|c|c|c|}
\hline & Kelompok & Median & $P$ \\
\hline \multirow{2}{*}{$\begin{array}{l}\text { Pretest } \\
\text { Kognitif }\end{array}$} & Intervensi & 53.50 & 0.865 \\
\hline & Kontrol & 52.14 & \\
\hline \multirow{2}{*}{$\begin{array}{l}\text { Postes } \\
\text { Kognitif }\end{array}$} & Intervensi & 92.55 & 0.000 \\
\hline & Kontrol & 73.93 & \\
\hline
\end{tabular}

Hasil belajar kognitif antara kelompok intervensi dan kelompok kontrol pada saat pretest tidak berbeda secara signifikan nilai

$P=0.865(\alpha=0.05)$ serta nilai rata-rata hasil belajar kognitif pada kedua kelompok sebelum intervensi relatif sama. Hasil belajar antara kelompok intervensi dan kelompok kontrol setelah dilakukan intervensi berbeda secara signifikan nilai $\mathrm{P}=0.000(\boldsymbol{\alpha}=0,05)$.

Hasil Uji Maan Whitney untuk variabel harga diri dapat dilihat pada tabel berikut ini:

Tabel 5. Perbedaan Harga Diri Mahasiswa Kelompok Intervensi dan Kelompok Kontrol Sebelum dan Sesudah Intervensi.

\begin{tabular}{lll}
\hline & Kelompok & $\mathrm{P}$ \\
\hline $\begin{array}{l}\text { Pretest Harga } \\
\text { diri }\end{array}$ & Intervensi & 0.550 \\
& Kontrol & \\
\hline $\begin{array}{l}\text { Postes Harga } \\
\text { diri }\end{array}$ & Intervensi & 0.000 \\
& Kontrol & \\
\hline
\end{tabular}

Harga diri pada kelompok intervensi dan kelompok kontrol sebelum dilakukan intervensi juga tidak berbeda signifikan dengan nilai $\mathrm{P}=0.550(\alpha=0.05)$. Setelah dilakukan intervensi terdapat perbedaan yang signifikan antara kelompok intervensi dan kelompok kontrol yaitu dengan nilai $P=0.000(\alpha=0.05)$.

\section{PEMBAHASAN}

Hasil penelitian menujukkan bahwa skor hasil belajar kognitif pada kelompok intervensi yang mendapatkan intervensi metode kooperatif Jigsaw mengalami peningkatan. Penelitian menunjukkan bahwa pembelajaran menggunakan cooperative jigsaw memberikan hasil yang memuaskan (Smith, 2010). Penelitian lain juga menunjukkan bahwa dengan penerapan metode cooperative jigsaw terjadi peningkatan dalam hasil belajar (Swachberger, 2014).

Hasil penelitian juga menunjukkan peningkatan hasil belajar kognitif tidak hanya terjadi pada kelompok intervensi saja, kelompok kontrol yang tidak mendapatkan metode kooperatif juga mengalami peningkatan median. Peningkatan median pada kelompok kontrol tidak setinggi peningkatan median pada kelompok intervensi. Hal tersebut menunjukkan bahwa kelompok mahasiswa yang mendapatkan intervensi kooperatif lebih meningkat dibandingkan dengan kelompok kontrol yang mendapatkan metode konvensional ceramah. Peningkatan median pada kelompok kontrol dapat terjadi karena responden sudah mengalami pembelajaran terhadap materi tersebut dengan metode konvensional. Kedua kelompok baik intervensi ataupun kelompok kontrol sudah mendapatkan materi dengan cara yang berbeda. Perubahan median hasil belajar pada kedua kelompok tersebut dikarenakan responden sudah mengalami pembelajaran.

Belajar merupakan kegiatan individu untuk memperoleh pengetahuan, ketrampilan, dan perilaku dengan cara mempelajari suatu materi atau bahan ajar (Sagala, 2009). Perubahan hasil belajar tersebut merupakan akibat dari proses pembelajaran yang telah dilalui. Pencapaian hasil belajar pada kedua kelompok tersebut tidak hanya merupakan hasil dari proses belajar di kelas saja, karena terdapat beberapa faktor yang mempengaruhinya yaitu factor intrinsik dan extrinsik.

Kemampuan teacher untuk menjadi role model akan membawa pengaruh dan perubahan terhadap aktifitas belajar mahasiswa. Hasil penelitian dapat dipengaruhi oleh dosen yang mengajar di kelompok kontrol merupakan salah satu dosen yang menjadi role model dari bagi mahasiswa, sehingga dapat meningkatkan motivasi mahasiswa dalam belajar, yang pada akhirnya dapat meningkatkan pengetahuan mahasiswa pada materi yang diajarkan. 
Proses pembelajaran juga mengandung input, proses, serta output yang dapat mempengaruhi hasil belajar. Metode pembelajaran termasuk salah satu komponen proses yang mempengaruhi hasil belajar. Kelompok intervensi dan kelompok kontrol menggunakan metode pembelajaran yang berbeda sehingga peningkatan hasil belajar yang dicapai juga berbeda walaupun kedua kelompok mengalami peningkatan rata- rata setelah mendapatkan proses pembelajaran.

Penilaian tharga diri mahasiswa terlihat dari penghargaan terhadap keberadaan dan keberartian diri. Dalam proses pembelajaran mahasiswa akan mempunyai harga diri yang tinggi ketika mahasiswa tersebut merasa diterima oleh pengajar ataupun teman dalam lingkungan belajarnya. Harga diri juga mencakup evaluasi dan penghargaan terhadap dirinya sendiri dan menghasilkan penilaian tinggi atau rendah terhadap dirinya sendiri.

Harga diri mahasiswa ketika proses pembalajaran merupakan penilaian mahasiswa itu sendiri saat proses pembelajaran berlangsung. Mahasiswa akan merasa dan meyakini bahwa dirinya dianggap mampu, penting , dan berharga saat proses pembelajaran.

Metode pembelajaran cooperative Jigsaw didalamnya terdapat langkah pembelajaran yang melibatkan semua mahasiswa menjadi tim ahli terhadap topik tertentu dalam metode pembelajaran. Semua mahasiswa dalam tim ahli juga akan diberikan kesempatan untuk mengajarkan topiknya ke teman kelompok asalnya. Kesempatan mahasiswa menjadi tim ahli tersebut dapat meningkatkan harga diri mahasiswa karena mahasiwa akan merasa bahwa dirinya mampu, penting dan dibutuhkan oleh anggota kelompok yang lainnya.

Peserta didik saling membantu, dengan demikian membangun sebuah komunitas yang mendukung, yang kemudian dapat meningkatkan kinerja masing-masing anggota. Kinerja dari masing-masing anggota kelompok tersebut akan meningkatkan harga diri mahasiswa.

Hasil Penelitian ini diperkuat oleh penelitian yang telah dilakukan sebelumnya. Hasil penelitian sebelumnya menunjukkan bahwa penerapan metode cooperative Jigsaw dapat meningkatkan nilai akademik dan motivasi intrinsik mahasiswa dibandingkan dengan metode pembelajaran langsung (direct instruction).

Penelitian yang dilakukan dengan responden mahasiswa keperawatan menunjukkan bahawa terdapat pengaruh metode pembelajaran Cooperative Learning terhadap harga diri mahasiswa dibandingkan dengan pembelajaran ceramah atau konvensional (Lie, 2014).

Penelitian ini mendukung dari hasil penelitian yang telah dilakukan Megahed tahun 2015 yaitu metode pembelajaran cooperative Jigsaw dapat meningkatkan harga diri mahasiswa

Hasil belajar pada kelompok intervensi jauh lebih tinggi dibandingakan dengan kelompok kontrol karena intervensi yang diberikan berbeda. Kelompok intervensi mendapatkan metode pembelajaran cooperative jigsaw yang didalamya terdapat lima unsur pokok yaitu saling ketergantungan positif, tanggung jawab perseorangan, tatap muka, komunikasi antar anggota kelompok, dan evaluasi proses kelompok.

Kelima unsur pembelajaran kooperatif tersebut dapat memberikan dampak positif terhadap kemampuan interpersonal mahasiswa di dalam pembelajaran dibandingkan dengan pembelajaran konvensional atau pembelajaran individualistik. Selain itu dampak positif dari pembeajaran kooperatif jigsaw adalah kepuasan individu ketika proses pembelajaran berlangsung, karena setiap individu di dalam kelompok dapat berkontribusi dalam kelompok dan membenatu anggota kelompok yang lain untuk dapat memahami materi, hal ini yang dapat meningkatkan percaya diri, motivasi serta harga diri mahasiswa dalam belajar(Earl, 2009).

Manfaat pembelajaran kooperatifjigsaw yaitu dapat meningkatkan motivasi mahasiswa, meningkatkan kemampuan responden dalam berpikir kritis, adanya motivasi intrinsik yang lebih besar untuk belajar dan mencapai sikap yang lebih positif terhadap pembelajaran serta harga diri yang lebih tinggi (Isjoni, 2009).

Proses pembelajaran cooperative jigsaw merupakan salah satu model pembelajaran yang dikembangkan oleh Slavin di Universitas Jonh Hopkins. Model ini 


\section{NURSING PRACTICES}

merupakan salah satu model pembelajaran kooperatif yang mengupayakan peserta didik mampu mengajarkan kepada peserta didik lain dan berusaha mengoptimalkan ke seluruh anggota kelompok yang lain sebagai satu tim untuk maju bersama (Arend, 2008). Dalam proses pembelajaran inilah mahasiswa dapat membangun pengetahuannya sekaligus perasaan yang diwujudkan dari perilaku peduli terhadap orang lain.

Model pembelajaran kooperatif ini dalam pelaksanannya peserta didik mampu memiliki banyak kesempatan mengemukakan pendapat dan mengolah informasi yang didapat, dapat meningkatkan ketrampilan komunikasi, anggota kelompok bertanggung jawab terhadap keberhasilan kelompoknya. Pembelajaran kooperatif jigsaw merupakan suatu model pembelajaran yang fleksibel. Banyak riset yang telah dilakukan berkaitan dengan pembelajaran kooperatif jigsaw. Riset tersebut secara konsisten menunjukkan bahwa dengan pembelajaran kooperatif ini mahasiswa yang terlibat memperoleh prestasi belajar yang lebih baik, mempunyai sikap yang lebih baik serta lebih postif terhadap pembelajaran.

Penelitian tentang pembelajaran kooperatif model jigsaw hasilnya menunjukkan bahwa interakasi kooperatif memiliki berbagai pengaruh positif terhadap peserta didik. Pengaruh positif tersebut adalah (1) meningkatkan hasil belajar peserta didik, (2) meningkatkan daya ingat. (3) dapat mencapai penalaran yang lebih tinggi, (4) mendorong tumbuhnya motivasi intrinsik, (5) meningkatkan hubungan interpersonal, (6) meningkatkan sikap positif peserta didik terhadap sekolah, (7) meningkatkan sikap positif peserta didik terhadap guru, (8) meningkatkan harga diri peserta didik, (9) meningkatkan perilaku sosial dan (10) meningkatkan keterampilan hidup bergotong royong (Lie, 2008).

Hasil penelitian tentang pengembangan model pembelajaran kooperatif jigsaw dalam upaya untuk meningkatkan kemandirian dan hasil belajar. Hasil penelitian menunjukkan bahwa penerapan metode kooperatif jigsaw meningkatkan kemandirian dan hasil belajar peserta didik (Wardani, 2010).
Penelitian ini mempunyai beberapa keterbatasan penelitian yaitu kelompok kontrol dan kelompok intervensi berada dalam satu tempat penelitian yang sama sehingga dapat menjadi faktor perancu yang tidak dikendalikan oleh peneliti. Pengambilan data postest antara kelompok intervensi dan kelompok kontrol tidak dilakukan pada waktu yang bersamaan sehingga dapat mempertinggi bias terhadap hasil penelitian.

\section{KESIMPULAN}

Kesimpulan penelitian ini adalah terdapat peningkatan hasil belajar kognitif dan harga diri mahasiswa melalui penerapan metode cooperative learning jigsaw. Saran untuk penelitian selanjutnya adalah dapat meneliti tentang penerapan metode cooperative learning tipe lainnya selain jigsaw, dan dapat meneliti dengan variabel dependen yang lainnya seperti kerjasama kelompok atau critical thingking.

\section{REFERENSI}

Anita, Lie. (2008). Cooperative Learning, Jakarta :PT Grasindo Gramedia Widiasarana Indonesia.

Chin- Min, H (2012). The Efectiveness of Cooperative Learning. Journal Of Engineering Education, 101 (1), 119 - 137.

Chin- Minhsiung (2010). Identification of Dysfunctional Cooprative Learning Teams Based on Student's Achievemnent. Journal of Engineering Education, 99 (1),45-54.

Coopersmith, Stanley. (2006). The Antecedents of Self Esteem. San Fransisco: W. H. Freeman.

Direktorat Jendral Pendidikan Tinggi Pembelajaran dan Kemahasiswaan (2015). Pedoman Kurikulum Pendidikan Tinggi, Jakarta.

Earl, G. L., PharmD. (2009). Using cooperative learning for a drug information assignment. American Journal of Pharmaceutical Education, 73(7), 1-132. Retrieved Hall, E. W. (2004). Regarding cooperative learning in rural special education classes. The Exceptional Parent, 34, 31-32,34.

Etchberger, R. C. (2011). Assessment of cooperative learning in natural resources education. Journal of Forestry, 109(7), 397-401.

Goodell, L. S., Cooke, N. K., \& Ash, S. L. (2012). Cooperative learning through in-class team work: An approach to classroom 
instruction in a life cycle nutrition course. NACTA Journal, 56(2), 68-75.

Hanson, M. J. S., \& Carpenter, D. R. (2011). Integrating cooperative learning into classroom testing: Implications for nursing education and practice. Nursing Education Perspectives, 32(4), 270-3.

Hanze, M \& Berger, R (2007). Cooperative Learning Jigsaw Classroom Motivational and Student Characteristic Effect. Experimental Study comparing cooperative Learning and Direct Instruction. Institte of Psychologycal. Journal Learning and Instruction. V 17. p 29-41.

Huang, H, et al (2013). A jigsaw Based Cooperative Learning Approach as Improvine Learning Outcome for Mobile Situated Learning. Journal of Technology Educational and Society. 17 (1). p 128-140.

Isjoni.(2009) Cooperative Learning, Efektifitas Pembelajaran Kelompok, Bandung: Alfabet.

Johnson David \& Roger Johnson.(2000).Leading The Cooperative School.Edina, MN: Interaction Book Company.

Johnson,D.W \& Johnson,R.T.(2005).Cooperative Learning And Social Interdependence Theory. http://www.clcrc.com. diakses 27 Oktober 2015.

Kim, J., Kim, M \& Svinicki, M. D (2012). Situating Student Motivation in Cooperative Learning Contexts; Proposing Different leves of Goals Orientation. Journal of Experimental Education, 80(4), 352-385.

Mari, J. S., \& Gumel, S. A. (2015). Effects of jigsaw model of cooperative learning on self-efficacy and achievement in chemistry among concrete and formal reasoners in colleges of education in nigeria. International Journal of Information and Education Technology, 5(3), 196-199

Megahed, M. M., \& Mohammad, F. A. (2014). Effect of cooperative learning on undergraduate nursing students' self-esteem: A quasi- experimental study. Journal of Nursing Education and Practice, 4(11), 1.

Mehran Takherani \& Zaleh Sadegian, (2015). Intrinsic Motivation Comparative Investigation Between Nursery, Midwery and Medicine Student in Iran. Procedia - Social and Behavioral Sciences 185,185-189.

Miftahul Huda. (2015). Cooperative Learning Metode, Teknik, Struktur dan Penerapan.Yogyakarta : Pustaka Pelajar.
Muhibbin Syah. (2008). Psikologi Belajar. Bandung : PT. Remaja Rosdakarya.

Slavin, Robert.(2008).Cooperative Learning Theory. USA:Allymand\&Bacon.

Slavin,Robert.(2013).Cooperative Learning(Teori, Riset,dan Praktek). Bandung: Nusamedia

Smith-Stoner, M., \& Molle, Mary E, PhD,R.N., P.H.C.N.S.B.C. (2010). Collaborative action research: Implementation of cooperative learning. Journal of Nursing Education, 49(6), 312-8. doi:http://dx.doi.org/10.3928/0148483420100224-06

Stahl.(1994).Cooperative Learning in Social Studies. New York:Addison Wesley Publishing Company.

Schwamberger, B., \& Sinelnikov, O. A. (2014). College students' perspectives, goals, and strategies using cooperative learning. Research Quarterly for Exercise and Sport, 85,1

Sugiyono. (2015). Statistika Untuk Penelitian, Bandung : Alfabeta.

Uys, L.R and Gwele, N.S. (2005) Curriculum Development in Nursing: Process and Innovation. London: Routledge), pp. $1-40$

Wardani., D \& Novianti (2010). Model Jigsaw dalam Perkuliahan Ilmu Ekonomi Untuk Meningkatkan Hasil Belajar. Jurnal Program Pendidikan Ekonomi. V 13(1) p.46-54.

Wyatt, T. H., Krauskopf, P. B., Gaylord, N. M., Ward, A., Huffstutler-Hawkins, S., \& Goodwin, L. (2010). Cooperative M-learning with nurse practitioner students. Nursing Education Perspectives, 31(2), 109-13.

Yueh-Min, H., Yi-Wen, L., Shu-Hsien Huang, \& Hsin-Chin, C. (2014). A jigsaw-based cooperative learning approach to improve learning outcomes for mobile situated learning. Journal of Educational Technology ES Society, 17(1), 128-140.

Zulharman, (2008). Inovation Of Medical Education. Diakses 30 November2015, darihttp://Zulharman79.wordpress. com/2007/07/15problembasedlearning/pbl. 